\title{
Quality and use of habitat patches by wild boar (Sus scrofa) along an urban gradient
}

\author{
D. Sütö ${ }^{1,2} \cdot$ M. Heltai ${ }^{1} \cdot$ K. Katona ${ }^{1}$
}

Received: 26 August 2019 / Accepted: 6 April 2020 / Published online: 25 May 2020

(c) The Author(s) 2020

\begin{abstract}
Expansion and urbanization process of wild boar (Sus scrofa) populations lead to serious human-wildlife conflicts in many cities, e.g. in Budapest, Hungary. In this study we evaluated the penetration potential of the species into the inner urban areas by identifying the occurrence of wild boar and the quality of the habitat patches for them along an urban gradient from the periphery towards the centre. Wild boar rooting intensity, shrub cover and the availability of woody species giving favourable food to wild boar were measured in four different habitat patches. The availability of hiding shrub patches was much higher in the outer areas than in the inner ones. Similarly, the proportion of shrub and tree species providing favourable food for wild boar decreased towards the centre. Accordingly, we found rooting only in two areas nearer to the city boundary. Based on our results at the peripheral areas permanent presence of wild boar in near-natural habitats should be expected, but not in the inner green zones. We recommend to monitor the urban wild boar presence and evaluate the quality of urban green patches to mitigate problems related to the wild boars.
\end{abstract}

Keywords Urbanization $\cdot$ Sus scrofa $\cdot$ Rooting $\cdot$ Human-wildlife conflict $\cdot$ Ungulates $\cdot$ Budapest

\section{Introduction}

Human population showed rapid growth in the past 100 years, thus the size and number of our settlements also increased at the expense of natural habitats (Aronson et al. 2017; Ersoy et al. 2019; Luniak 2004; Patterson et al. 2003; Stillfried et al. 2017b; Toger et al. 2018). Currently, more than half of the World's human population lives in towns and cities, whereas this ratio in Europe is about $80 \%$ (Antrop 2004; Cohen 2006). In the last 20 years along the rising trend of urbanization, the borders of the human habitats extended considerably (UN 2019). With the growth of the human population and the expansion of the cities and their agglomerations, contact zones were formed at the border of natural and anthropogenic habitats (Cahill et al. 2012).

D. Sütő

suto.david@mkk.szie.hu

1 Department of Wildlife Biology, Szent István University, Institute for Natural Resources Conservation, Páter Károly utca 1, Gödöllő 2100, Hungary

2 Department of Systematic Zoology and Ecology, Eötvös Loránd University, Pázmány Péter sétány 1/C, Budapest 1117, Hungary
Species with good adaptability and broad niche tolerance can thrive in these new habitats (Jokimäki et al. 2011, Schilthuizen 2018). Nowadays it is common to encounter red foxes (Vulpes vulpes), stone martens (Martes foina), roe deer (Capreolus capreoulus) or wild boars (Sus scrofa) in the urban and sub-urban areas of Europe (Bateman and Fleming 2012; Ciach and Fröhlich 2019; Herr et al. 2009; Luniak 2004). However, coexistence with these species can cause many problems in the everyday life of the citizens (Bateman and Fleming 2012; Cahill et al. 2012; Lyytimäki et al. 2008; Stillfried et al. 2017a).

In Hungary - and in many countries in Europe and other continents-one of the most troublesome species entering human settlements is the wild boar (Licoppe et al. 2013; Stillfried et al. 2017a). Wild boar is one of the most widespread mammal species in the World (Massei et al. 2015). Its natural habitat extends from Western Europe through the Mediterranean to East Russia, Japan and Southeast Asia. But the populations of the species are expanding and also spreading to Northern Europe, reappearing in many of the Scandinavian countries. Nowadays, wild boars are already present in many of the bigger towns and cities in Europe like Berlin, Barcelona, Rome, Vilnius, Belgrade and Budapest (CastilloContreras et al. 2018; Massei et al. 2015; Podgórski et al. 
2013; Stillfried et al. 2017a, b). Wild boar is a broad niche species which can easily adapt to the urban environment (Cahill et al. 2012; Podgórski et al. 2013; Stillfried et al. 2017a; Toger et al. 2018).

Wild boars are social animals, living in groups; they are robust, equipped with tusks, by which they can cause serious physical injuries to humans or to companion animals (Mackenstedt et al. 2015; Meng et al. 2009). Moreover, as an omnivorous ungulate, wild boars are often attracted by communal waste and scavenge the bins or illegal waste disposals (Castillo-Contreras et al. 2018; Hafeez et al. 2011; Licoppe et al. 2013; Podgórski et al. 2013; Toger et al. 2018), although Hungarian studies did not prove the importance of waste as a food source for the species (Heltai et al. 2016c). Species-related issues also include the growing number of wildlife collisions near and inside the cities as a threatening factor to safe traffic and causing serious financial costs to car owners (Cahill et al. 2012; Kotulski and König 2008; Licoppe et al. 2013; Seymour et al. 2006). Actually, the spreading of African swine fever and the transmission of the disease from wild to domestic pigs is also an unsolved problem in Europe (Costard et al. 2013; Sánchez-Vizcaíno et al. 2015). However, the majority of the conflicts are coming from the rooting behaviour of the species which can cause damages in the ornamental and vegetable gardens, flower beds, public parks and lawns (Bogdán and Heltai 2014). Therefore, they can cause economic damages, ruin recreational green areas of the cities and endanger the public safety in urban districts (Cahill et al. 2012; Castillo-Contreras et al. 2018).

Nevertheless, we have an insufficient knowledge about the behaviour of the wild boar in urban areas and the main factors having role in attracting them to the cities and ensuring their survival near to humans. According to previous studies we already know that wild boars are not only occasional visitors in the cities, but they tend to spend significant part of the year inside the city boundaries (Castillo-Contreras et al. 2018; Heltai et al. 2016b; Kotulski and König 2008). Wild boars can be attracted into the towns by easily accessible anthropogenic food (e.g. compost, illegal green waste disposals, leftovers in the waste or pet food but sometimes people deliberately feed them) and other optimal environmental circumstances that can often form at contact zones, like remnant, near-natural forest patches or neglected green areas (private gardens, public parks). Well-kept green areas attract wild boars when managed by irrigation, because it can create ideal circumstances for rooting and wallowing. Not least, the lack of hunting might be also an important aspect in wild boar urbanization (Bogdán and Heltai 2014; Castillo-Contreras et al. 2018; Csókás and Heltai 2016; Heltai et al. 2016b; Licoppe et al. 2013).

In this study our aim was to reveal the role of urban forested areas in the penetration process of wild boar into a big city, namely Budapest, the capital of Hungary. We investigated the availability of woody vegetation providing hiding place and natural seed and fruit food sources and the occurrence of wild boar in different habitat patches along an urban gradient. We hypothesized that the urbanization of the wild boars is promoted with the increasing similarity of the inner green urban areas in their vegetation characteristics to the more natural habitats at the peripheral city areas and outside of it.

\section{Materials and methods}

\section{Study area}

Our study was carried out in Budapest $\left(47^{\circ} 29^{\prime} \mathrm{N}, 19^{\circ} 9^{\prime} \mathrm{E}\right)$, one of the largest cities in Central Europe. The city occupies $525 \mathrm{~km}^{2}$ and has a population of 1.7 million people. The city is divided by the Danube river and lies at a junction of two major landscapes. The western half of the city is called Buda and characterized by low mountain range hills and valleys, while the eastern side, Pest comprises the Danube floodplain. The annual mean precipitation of the city is $533 \mathrm{~mm}$, but increases with the altitude in the Buda Hills. The annual mean temperature is about $11^{\circ} \mathrm{C}$, lowest in January $\left(0.4{ }^{\circ} \mathrm{C}\right)$ and highest in July $\left(21.1^{\circ} \mathrm{C}\right)$ (Tóth-Ronkay et al. 2015). The surrounding area of the city has a rich and diverse flora and fauna. Within the boundaries of Budapest significant part of the city (47\%) is covered by green areas and some of them are also parts of the Natura 2000 network. However, much of those urban green areas are neglected and the legal responsibilities of the properties are often unclear. It is not unusual that the manager and the owner of a green area are different, which makes the implementation of any efficient management difficult. It is also an important issue, that the maintenance of green areas of the city is severely underfunded (Molnár et al. 2017). Wild boar was always present in the forested areas around the capital, but it has been increasingly appearing within the urban zones since 2000 (Tari et al. 2018).

We investigated four study sites along an urban gradient (Fig. 1): (1) The area of János-hill and Normafa; (2) Széchenyihegy; (3) Farkasrét Cemetery; (4) Gellért-hill. All of them are situated in the western half of the city. There, probably due to the network of larger seminatural woodland patches and their direct connection to the forests outside the city boundaries, frequent wild boar occurrences have already been registered and expected. We designated the study sites along a northwest-southeast axis, from the western border of the city towards the centre perpendicular to the direction of flow of the Danube. The allotted green areas can potentially form an ecological corridor for the wild boar to the centre of the city. 
Fig. 1 Location of the study sites in Budapest (with the name of the two parts of the city indicated on the map)

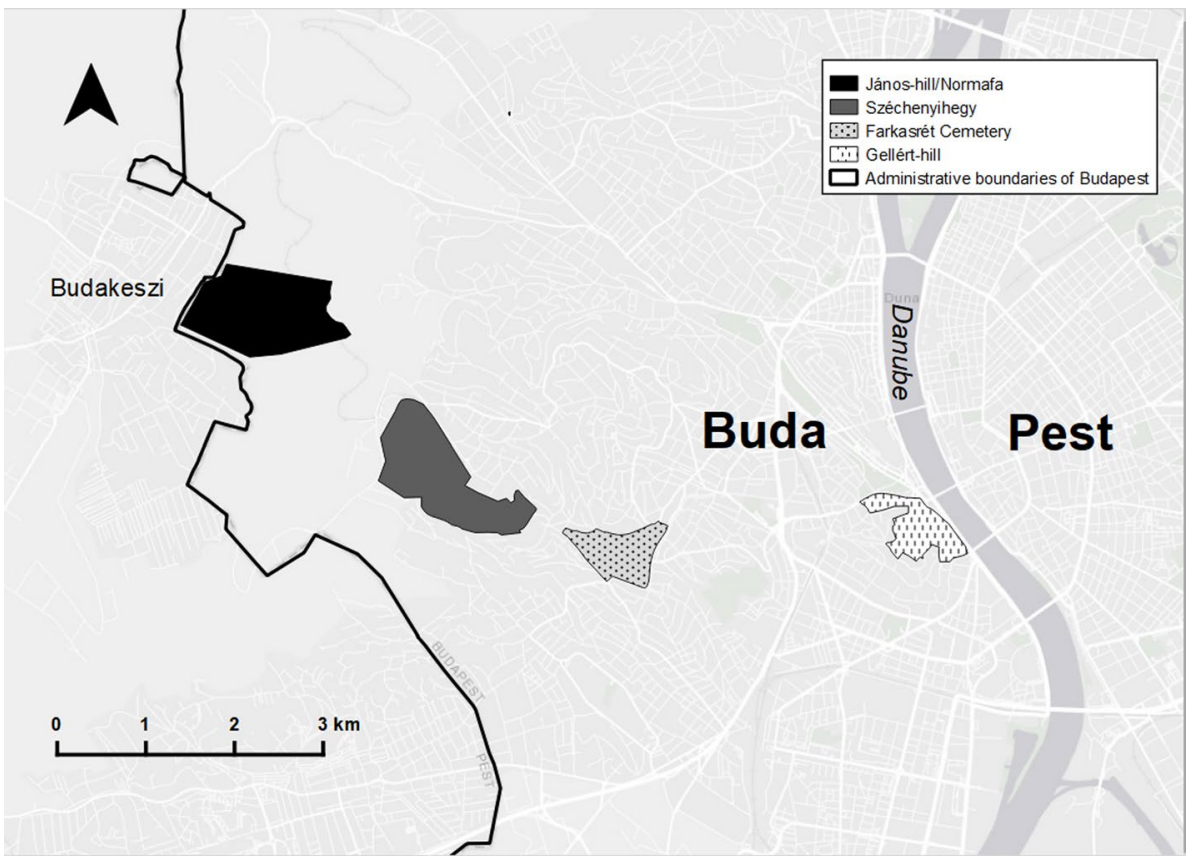

The study sites are parts of Buda Hills, which is the eastern segment of the Transdanubian Mountains. The bedrocks of the area are mainly limestone and dolomite. The most peripheral study site was the area of János-hill and Normafa situated in the protruding part of the Budakeszi Forest to Budapest from outside of the city borders. The size of this area is about 133 ha. The most important plant communities of the area of Janos-hill and Normafa are the Turkey oak (Quercus cerris)-sessile oak (Quercus petraea), sessile oakhornbeam (Carpinus betulus) and beech (Fagus sylvatica) forests, moreover the mixed woodlands of slopes and screes, but dolomitic scrubs can also be found. This study site is popular destination for hikers and tourists since the 17 th century.

The Széchenyihegy is also a favoured recreational location. The size of the area is about 121 ha. Its typical vegetation consists of termophilic oak woodlands and dolomitic scrubs

The Farkasrét Cemetery is one of the most considerable graveyard in Hungary. It was founded in 1894 and nowadays the size of the cemetery reached its limits with 42 ha. The present appearance of the cemetery is the result of a high intensity landscaping in the 1950's. Therefore, the flora of the site is highly anthropogenic. The cemetery is a fenced area; however there are several observations of wild boar presence by local employees and our previous pilot studies. Wild boar often uses less disturbed fenced areas (e.g. abandoned gardens) within Budapest (Bogdán and Heltai 2014).

The Gellért-hill has an area of 42.3 ha, which is a popular location next to the Danube. The area is one of the major tourist attractions in Budapest. The Gellért-hill is part of the
UNESCO World Heritage Sites since 1987 and functions as a nature conservation area since 1997 . The vegetation of the area is highly artificial due to the fact that it serves as a public park for the citizens for a long time. The northern and western side of the Gellért-hill is largely occupied by forest-like woody stands, there the traces of the former natural plant communities like sessile oak-hornbeam, ash (Fraxinus spp.) and maple (Acer spp.) woodlands are still recognizable. The eastern side is bordered by steep rocky slopes, meanwhile the southwestern part is more dominated by well-groomed park-like territories.

There is no accessible natural surface-water for the animals (e.g. streams and ponds) on either of the study sites, although wells can be found both at Farkasrét Cemetery and Gellért-hill.

\section{Field data collection}

The data collection was carried out between January and May in 2018. The outer areas were investigated during winter, but investigation in the inner, more anthropogenic sites was scheduled to the spring, to be able to identify more reliably the expected large amount of non-native plant species. The timing and the difference in the data collection should not cause important bias to our results, since our aim was to measure those kinds of variables which can reflect circumstances of a longer time period (i.e. to recognize stable suitable habitat patches and wild boar presence which is permanent throughout the year (Bogdán and Heltai 2014)).

In each study site transects were designated for our surveys. A sampling unit was appointed in every $10 \mathrm{~m}$ along 
these transects, meaning 100 sampling units per $1 \mathrm{~km}$ per area (except Széchenyihegy, where the shrub species were identified in June at 100 sampling units, but the other estimations were accomplished in February at 379 sampling units). The sampling units were circles of $10 \mathrm{~m}^{2}(\mathrm{r}=1.78 \mathrm{~m})$.

Within the sampling circles we evaluated the total ground cover of the shrubs which can provide shelter for wild boars into five categories $(0 \% ; 1-25 \% ; 26-50 \% ; 51-75 \%$; $76-100 \%)$. Using the distribution of sampling units along these five classes the total surface area of each site occupied by shrub shelter was also calculated.

We also determined the occurrence of woody species in the understory by identifying the nearest shrub individual to the centre of the sampling unit at four points in the four directions of the compass (therefore, $0-4$ species were registered in every sampling units). In case of the lack of shrubs within the unit of $1.78 \mathrm{~m}$ radius, we extended our search beyond that distance, but only up to $5 \mathrm{~m}$. We also recorded the tree species composition in this manner, but in that case tree individuals higher than $2 \mathrm{~m}$ were only registered (above the understory layer providing shelter). Shrub and tree species were categorized according to their fruits and seeds, whether they mean a potentially good food source for the wild boars or not. This grouping was based on the publications on plant species characteristics by Bordás and Tompa (2006), Fekete et al. (2003) and dietary researches of wild boar (Heltai et al. 2016a, b, c; Katona and Heltai 2018).

To detect wild boar presence in the study sites the proportion of the rooted ground surface in the sampling units was estimated and classified into 5 categories $(0 \% ; 1-25 \%$; $26-50 \%$; $51-75 \%$; 76-100\%). The intensity of the rooting was split into 3 levels: 1 . litter disturbances; 2 . upper soil disturbances; 3 . deeper soil disturbances.

Additionally, in the Farkasrét Cemetery, we evaluated the ground cover of the graves (which are usually made of some hard material like concrete or marble) by the method we used for shrub cover evaluation. These artificial structures can provide lateral coverage functioning as hiding places to wild boars, but also prevent rooting or growing of vegetation, influencing our results.

\section{Data analysis}

For data analysis and visualization, we used the Microsoft Office Excel 2016. We made comparisons along the urban gradient for all datasets of measured variables. In terms of hiding place availability, the proportions of shrub cover were matched among the four study sites. From the aspect of food availability, we compared the woody species composition in the understory (mainly shrubs) and overstory (trees), namely the whole list of available species, the number of species, the proportion of native and alien species (reflecting the naturalness of the area supposed to promote wild boar occurrence), and especially the proportion of the plant species providing potential good food for the wild boars. Occurrence of wild boar (its penetration towards the city centre) was analysed by collating the data on the abundance of wild boar rooting in the four study sites. For statistical analyses we used Chi square test for homogeneity.

\section{Results}

\section{Shrub cover and species composition in the study sites}

In the János-hill and Normafa area, in the Budakeszi Forest at the boundaries of Budapest, the appropriate shrub shelter was lacking only in $15 \%$ of the sampling units. More than half of the sampling units (53\%) had 1-25\% shrub cover. Altogether, $34.5 \%$ of the surface of the study site was covered by woody understory. In the shrub layer 12 woody plant species were found. All the species were native, from which three were dominant, the common hawthorn (Crataegus monogyna, $33 \%$ of the all shrub individuals), the European cornel (Cornus mas, 28\%) and the common dogwood (Cornus sanguinea, $24 \%$ ). The proportion of the other species were under 5\% (Table 1). In regard of the trees, 13 species were identified and all of them were indigenous. The dominant species were sessile oak (42\%) and flowering ash (Fraxinus ornus, 20\%). In case of other appearing species, the frequency of beech (7\%), Turkey oak (6\%), common ash (Fraxinus excelsior, 6\%), field maple (Acer campestre, 5\%) and wild cherry (Prunus avium, 5\%) were considerable (Table 2).

At the Széchenyihegy study site only $9 \%$ of the sampling units was nudum without shrub shelter. More than half of the sampling units (52\%) was classified into the $1-25 \%$ shrub cover group. In this site the $39.25 \%$ of the total surface was occupied by woody understory. The shrub layer was quite diverse, there were 25 species registered and only three of them were alien (12\%) (Table 1). Field maple (23\%), - surprisingly a non-native species - the common lilac (Syringa vulgaris, 13\%) and European bladdernut (Staphylea pinnata, $11 \%$ ) had the highest frequency. The composition of the tree species was also relatively diverse, 13 native and one alien species were identified (93\% and 7\%, respectively) (Table 2). The frequency of sessile oak (38\%) and Turkey oak (20\%) were the most considerable. But the occurrence of Pinus spp. (10\%), common ash (9\%) and wild cherry (6\%) were also relatively high.

In the Farkasrét Cemetery 65\% of the sampling units were found without any shrub cover, $22 \%$ showed $1-25 \%$ understory cover, meanwhile the remaining $13 \%$ had higher shrub coverage. Consequently, only $13.5 \%$ of the ground surface was occupied by woody understory. In the Cemetery the 
Table 1 Species composition of the woody understory in the different urban areas

\begin{tabular}{|c|c|c|c|c|c|c|}
\hline \multirow[b]{2}{*}{ Species list } & \multirow[b]{2}{*}{ Favourable/Other } & \multirow[b]{2}{*}{ Native/Alien } & \multicolumn{4}{|c|}{ Proportion of individuals (\%) } \\
\hline & & & $\begin{array}{l}\text { János-hill/ } \\
\text { Normafa }\end{array}$ & Széchenyihegy & $\begin{array}{l}\text { Farkasrét } \\
\text { Cemetery }\end{array}$ & Gellért-hill \\
\hline Acer campestre & Other & Native & 0 & 22.9 & 1 & 1.1 \\
\hline Acer platanoides & Other & Native & 0 & 5.2 & 20.6 & 12.5 \\
\hline Acer pseudoplatanus & Other & Native & 0 & 1.3 & 0 & 0 \\
\hline Ailanthus altissima & Other & Alien & 0 & 1.7 & 1 & 0 \\
\hline Berberis amurensis & Other & Alien & 0 & 0 & 0 & 1.1 \\
\hline Berberis julianae & Other & Alien & 0 & 0 & 1 & 1.1 \\
\hline Carpinus betulus & Other & Native & 0 & 0.9 & 0 & 0 \\
\hline Celtis occidentalis & Favourable & Alien & 0 & 0 & 0 & 2.3 \\
\hline Chamaecyparis lawsoniana & Other & Alien & 0 & 0 & 1 & 0 \\
\hline Clematis vitalba & Other & Native & 0.3 & 0 & 0 & 0 \\
\hline Cornus mas & Favourable & Native & 27.8 & 2.6 & 0 & 4.5 \\
\hline Cornus sanguinea & Other & Native & 24.4 & 7.4 & 1 & 1.1 \\
\hline Coryllus avellana & Favourable & Native & 0 & 0.9 & 0 & 0 \\
\hline Cotoneaster horizontalis & Other & Alien & 0 & 0 & 0 & 5.7 \\
\hline Cotoneaster multiflorus & Other & Alien & 0 & 0 & 1 & 15.9 \\
\hline Crataegus laevigata & Favourable & Native & 5.6 & 0.4 & 0 & 0 \\
\hline Crataegus monogyna & Favourable & Native & 26.9 & 6.1 & 0 & 0 \\
\hline Cupressus sempervirens & Other & Alien & 0 & 0 & 1 & 0 \\
\hline Cytisus scoparius & Other & Native & 0 & 0 & 0 & 1.1 \\
\hline Euonymus europaea & Other & Native & 0 & 0 & 1 & 0 \\
\hline Euonymus japonicus & Other & Alien & 0 & 0 & 6.2 & 0 \\
\hline Euonymus verrucosus & Other & Native & 3.1 & 0.9 & 0 & 0 \\
\hline Ficus carica & Favourable & Alien & 0 & 0 & 0 & 3.4 \\
\hline Fraxinus excelsior & Other & Native & 0 & 3.5 & 0 & 0 \\
\hline Fraxinus ornus & Other & Native & 0 & 3.5 & 2.1 & 2.3 \\
\hline Hedera helix & Other & Native & 0 & 0 & 10.3 & 0 \\
\hline Juglans regia & Other & Alien & 0 & 0 & 2.1 & 0 \\
\hline Juniperus chinensis & Other & Alien & 0 & 0 & 5.2 & 0 \\
\hline Ligustrum vulgare & Other & Native & 4.4 & 3.9 & 2.1 & 1.1 \\
\hline Lonicera spp. & Other & Alien & 0 & 0 & 1 & 5.7 \\
\hline Mahonia aquifolium & Other & Alien & 0 & 0 & 1 & 0 \\
\hline Malus spp. & Favourable & Native & 0 & 1.7 & 0 & 0 \\
\hline Picea engelmannii & Other & Alien & 0 & 0 & 1 & 0 \\
\hline Platycladus orientalis & Other & Alien & 0 & 0 & 1 & 0 \\
\hline Prunus spinosa & Favourable & Native & 1.6 & 0 & 0 & 0 \\
\hline Prunus spp. & Favourable & Alien & 0 & 3 & 0 & 3.4 \\
\hline Quercus petraea & Other & Native & 0 & 0.4 & 0 & 0 \\
\hline Quercus pubescens & Other & Native & 0 & 1.3 & 0 & 0 \\
\hline Robinia pseudoacacia & Other & Alien & 0 & 0 & 1 & 4.5 \\
\hline Rosa canina & Favourable & Native & 0.3 & 3 & 0 & 0 \\
\hline Rosa spp. & Other & Alien & 0 & 0 & 22.7 & 6.8 \\
\hline Rubus spp. & Favourable & Native & 0.6 & 0 & 0 & 0 \\
\hline Sambucus nigra & Favourable & Native & 3.4 & 0 & 5.2 & 10.2 \\
\hline Sorbus torminalis & Other & Native & 0 & 0.9 & 0 & 0 \\
\hline Staphylea pinnata & Favourable & Native & 1.6 & 10.8 & 0 & 0 \\
\hline Syringa vulgaris & Other & Alien & 0 & 12.6 & 3.1 & 14.8 \\
\hline Taxus baccata & Other & Native & 0 & 0 & 6.2 & 0 \\
\hline
\end{tabular}


Table 1 (continued)

\begin{tabular}{|c|c|c|c|c|c|c|}
\hline \multirow[b]{2}{*}{ Species list } & \multirow[b]{2}{*}{ Favourable/Other } & \multirow[b]{2}{*}{ Native/Alien } & \multicolumn{4}{|c|}{ Proportion of individuals (\%) } \\
\hline & & & $\begin{array}{l}\text { János-hill/ } \\
\text { Normafa }\end{array}$ & Széchenyihegy & $\begin{array}{l}\text { Farkasrét } \\
\text { Cemetery }\end{array}$ & Gellért-hill \\
\hline Thuja occidentalis & Other & Alien & 0 & 0 & 1 & 0 \\
\hline Tilia spp. & Other & Native & 0 & 3.0 & 0 & 0 \\
\hline Ulmus spp. & Other & Native & 0 & 0.9 & 0 & 0 \\
\hline Viburnum lantana & Other & Native & 0 & 1.3 & 0 & 0 \\
\hline Viburnum opulus & Other & Native & 0 & 0 & 0 & 1.1 \\
\hline Proportion of native individuals (\%) & & & 100 & 82.7 & 49.5 & 35.2 \\
\hline Proportion of alien individuals (\%) & & & $\mathbf{0}$ & $\mathbf{1 7 . 3}$ & 50.5 & 64.8 \\
\hline Number of species & & & 12 & 25 & 25 & 20 \\
\hline
\end{tabular}

structure of graves limited the suitable surface for vegetation growth or rooting for food, since in $92 \%$ of the sampling units the graves were present. In $58 \%$ of the cases only half or less of the sampling unit was covered by the gravestones, while in $20 \%$ of the sample circles it reached the $75-100 \%$ category. In summary it means that $52 \%$ of the total ground surface of the study site was occupied by gravestones.

In the Cemetery a relatively high amount of shrub species was identified ( 25 species), although more than half of them were non-native species (16 species-64\%) (Table 1). Abundance of Rosaceae species were the highest (23\%). The young individuals of Norway maple (Acer platanoides) were quite abundant in the shrub layer (21\%), but the frequency of common ivy (Hedera helix, 10\%) forming a bushy mass, Japanese spindle (Euonymus japonicas, 6\%), common yew (Taxus baccata, 6\%), black elder (Sambucus nigra, 5\%) and Chinese juniper (Juniperus chinensis, 5\%) were also notable. Similarly, high number of tree species were identified (21 species) and like in case of shrubs approx. half of the species was not a native one (10 species-48\%) (Table 2). The proportion of common ash in the composition was outstanding (37\%), besides that two other ash species the flowering and the narrow-leafed ash (Fraxinus angustifolia) were also present (5-5\%). The proportion of Norway maple was also considerable in the canopy (16\%). Norway spruce (Picea abies, $8 \%$ ) and common horse chestnut (Aesculus hippocastanum, $6 \%$ ) were also common.

In the innermost site, the Gellért-hill, the shrub cover was entirely missing in more than half of the sampling units (57\%), in $20 \%$ of them the shrub cover was $1-25 \%$, while the remaining units showed a higher hiding place availability. Therefore, only $20 \%$ of the full study site provided appropriate shrub layer as shelter. During the investigation 20 shrub species were identified, again roughly half of the species were native ( 9 species-45\%). Showy cotoneaster (Cotoneaster multiflorus) was revealed with the highest frequency (16\%) followed by common lilac (15\%), Norway maple (13\%), black elder (10\%), Rosa spp. (7\%), Lonicera spp.
(6\%), wall cotoneaster (Cotoneaster horizontalis, 6\%), European cornel (5\%) and black locust (Robinia pseudoacacia) (5\%) (Table 1). The Gellért-hill site obtained the highest tree diversity consisting of 30 species, from which 17 were native ones (57\%). Among them common ash (19\%) and Norway maple $(17 \%)$ were dominant. Flowering ash, field maple, black locust and Prunus spp. were also relatively common (8\% for all) (Table 2).

\section{Changes of habitat characteristics and wild boar occurrence along an urban gradient}

Comparing the study sites along an urban gradient a decrease in the availability of shrub shelter in the central sites relative to the peripheral ones can be discovered (Fig. 2). The proportion of sampling units with woody understory were $85 \%$ at János-hill, 91\% at Széchenyihegy, 35\% at Farkasrét Cemetery and $43 \%$ at Gellért-hill. This difference was mainly due to the higher proportion of sample circles of 1-25\% shrub cover category at the peripheral sites than at the inner ones ( $53 \%$ and $52 \%$ vs. $22 \%$ and $20 \%$, respectively).

Similar results were found in terms of the total surface area occupied by shrubs. Its value was $34.5 \%$ at János-hill, $39.25 \%$ at Széchenyihegy, $13.5 \%$ at Farkasrét Cemetery and $20 \%$ at Gellért-hill. The proportion of the ground surface covered by shrubs differed significantly among the four study sites (Chi square test: $\mathrm{df}=3, \chi^{2}=24.25, P<0.0001$ ).

The species richness of woody plants has increased towards the city centre. In the shrub layer we identified 11 species at János-hill, 25 at Széchenyihegy and at Farkasrét Cemetery, while there were 20 species registered at Gellérthill. The diversity of tree species composition showed more obvious increase in the direction of central zones. At Jánoshill 13 tree species were identified, 15 species at Széchenyihegy, 21 species at Farkasrét Cemetery, while 30 species at Gellért-hill.

However, the proportion of non-indigenous species both in the understory and canopy level increased towards the 
Table 2 Species composition of the overstory in the different urban areas

\begin{tabular}{|c|c|c|c|c|c|c|}
\hline \multirow[b]{2}{*}{ Species } & \multirow[b]{2}{*}{ Favourable/Others } & \multirow[b]{2}{*}{ Native/Alien } & \multicolumn{4}{|c|}{ Proportion of individuals (\%) } \\
\hline & & & $\begin{array}{l}\text { János-hill/ } \\
\text { Normafa }\end{array}$ & Széchenyihegy & $\begin{array}{l}\text { Farkasrét } \\
\text { Cemetery }\end{array}$ & Gellért-hill \\
\hline Acer campestre & Others & Native & 5 & 0.7 & 2.3 & 8.1 \\
\hline Acer negundo & Others & Alien & 0 & 0 & 0 & 0.3 \\
\hline Acer platanoides & Others & Native & 0.3 & 0.5 & 16 & 17 \\
\hline Acer pseudoplatanus & Others & Native & 0 & 3.4 & 0.5 & 1.4 \\
\hline Aesculus hippocastanum & Others & Alien & 0 & 0 & 5.9 & 1.4 \\
\hline Ailanthus altissima & Others & Alien & 0 & 0 & 0 & 0.3 \\
\hline Alnus glutinosa & Others & Native & 0 & 0 & 0 & 0.3 \\
\hline Betula pendula & Others & Native & 0 & 0 & 0.5 & 0.6 \\
\hline Carpinus betulus & Others & Native & 2.5 & 3.1 & 0 & 0 \\
\hline Cedrus spp. & Others & Alien & 0 & 0 & 0 & 0.8 \\
\hline Celtis occidentalis & Favourable & Alien & 0 & 0 & 0 & 1.4 \\
\hline Cercis siliquastrum & Others & Alien & 0 & 0 & 0 & 1.1 \\
\hline Chamaecyparis lawsoniana & Others & Alien & 0 & 0 & 3.2 & 0 \\
\hline Coryllus avellana & Favourable & Native & 0 & 0 & 0 & 0 \\
\hline Coryllus colurna & Favourable & Alien & 0 & 0 & 0 & 2.2 \\
\hline Crataegus monogyna & Favourable & Native & 0 & 4.2 & 0 & 0.3 \\
\hline Cupressus spp. & Others & Alien & 0 & 0 & 0 & 0.8 \\
\hline Fagus sylvatica & Favourable & Native & 7.3 & 0 & 0 & 0 \\
\hline Fraxinus angustifolia & Others & Native & 0 & 0 & 4.6 & 0.6 \\
\hline Fraxinus excelsior & Others & Native & 5.5 & 9.6 & 37.4 & 19.2 \\
\hline Fraxinus ornus & Others & Native & 19.6 & 2 & 5 & 7.8 \\
\hline Ginkgo biloba & Others & Alien & 0 & 0 & 0 & 1.4 \\
\hline Juglans regia & Favourable & Alien & 0 & 0 & 3.2 & 0 \\
\hline Koelreuteria paniculata & Favourable & Alien & 0 & 0 & 0 & 2.5 \\
\hline Picea abies & Others & Native & 0 & 0 & 8.2 & 0 \\
\hline Picea pungens & Others & Alien & 0 & 0 & 0.5 & 0 \\
\hline Pinus nigra & Others & Alien & 0 & 7.4 & 0.5 & 0.8 \\
\hline Platycladus orientalis & Others & Alien & 0 & 0 & 4.1 & 0 \\
\hline Populus alba & Others & Native & 0 & 0 & 0 & 0.6 \\
\hline Populus balsamifera & Others & Alien & 0 & 0 & 0.5 & 0 \\
\hline Prunus avium & Favourable & Native & 4.8 & 7.7 & 0 & 0 \\
\hline Prunus spp. & Favourable & Native & 0 & 0 & 1.4 & 8.1 \\
\hline Quercus cerris & Favourable & Native & 5.8 & 17.5 & 0 & 0 \\
\hline Quercus petraea & Favourable & Native & 41.7 & 39.3 & 0 & 3.3 \\
\hline Quercus robur & Favourable & Native & 0 & 0 & 0 & 0.6 \\
\hline Rhus typhina & Others & Alien & 0 & 0 & 0 & 0.3 \\
\hline Robinia pseudoacacia & Others & Alien & 0 & 0 & 0.5 & 7.8 \\
\hline Salix babylonica & Others & Alien & 0 & 0 & 0.5 & 0 \\
\hline Sorbus borbasii & Others & Native & 0 & 0 & 0 & 0.6 \\
\hline Sorbus spp. & Others & Native & 0 & 0 & 0 & 0.3 \\
\hline Sorbus torminalis & Favourable & Native & 1.8 & 4.2 & 0 & 0 \\
\hline Taxus baccata & Others & Native & 0 & 0 & 2.7 & 0 \\
\hline Thuja occidentalis & Others & Alien & 0 & 0 & 1.4 & 0 \\
\hline Tilia cordata & Others & Native & 3.5 & 0 & 0 & 0 \\
\hline Tilia platyphyllos & Others & Native & 1 & 0 & 0 & 0 \\
\hline Tilia spp. & Others & Native & 0 & 0.1 & 1.4 & 6.4 \\
\hline Ulmus minor & Others & Native & 1.3 & 0 & 0 & 0 \\
\hline
\end{tabular}


Table 2 (continued)

\begin{tabular}{|c|c|c|c|c|c|c|}
\hline \multirow[b]{2}{*}{ Species } & \multirow[b]{2}{*}{ Favourable/Others } & \multirow[b]{2}{*}{ Native/Alien } & \multicolumn{4}{|c|}{ Proportion of individuals (\%) } \\
\hline & & & $\begin{array}{l}\text { János-hill/ } \\
\text { Normafa }\end{array}$ & Széchenyihegy & $\begin{array}{l}\text { Farkasrét } \\
\text { Cemetery }\end{array}$ & Gellért-hill \\
\hline Ulmus spp. & Others & Native & 0 & 0 & 0 & 3.9 \\
\hline Proportion of native individuals (\%) & & & 100 & 92.6 & 79.9 & 78.8 \\
\hline Proportion of alien individuals (\%) & & & $\mathbf{0}$ & 7.4 & 20.1 & 21.2 \\
\hline Number of species & & & 13 & 14 & 21 & 30 \\
\hline
\end{tabular}

Fig. 2 Hiding place availability to wild boars by shrubs in the four study sites

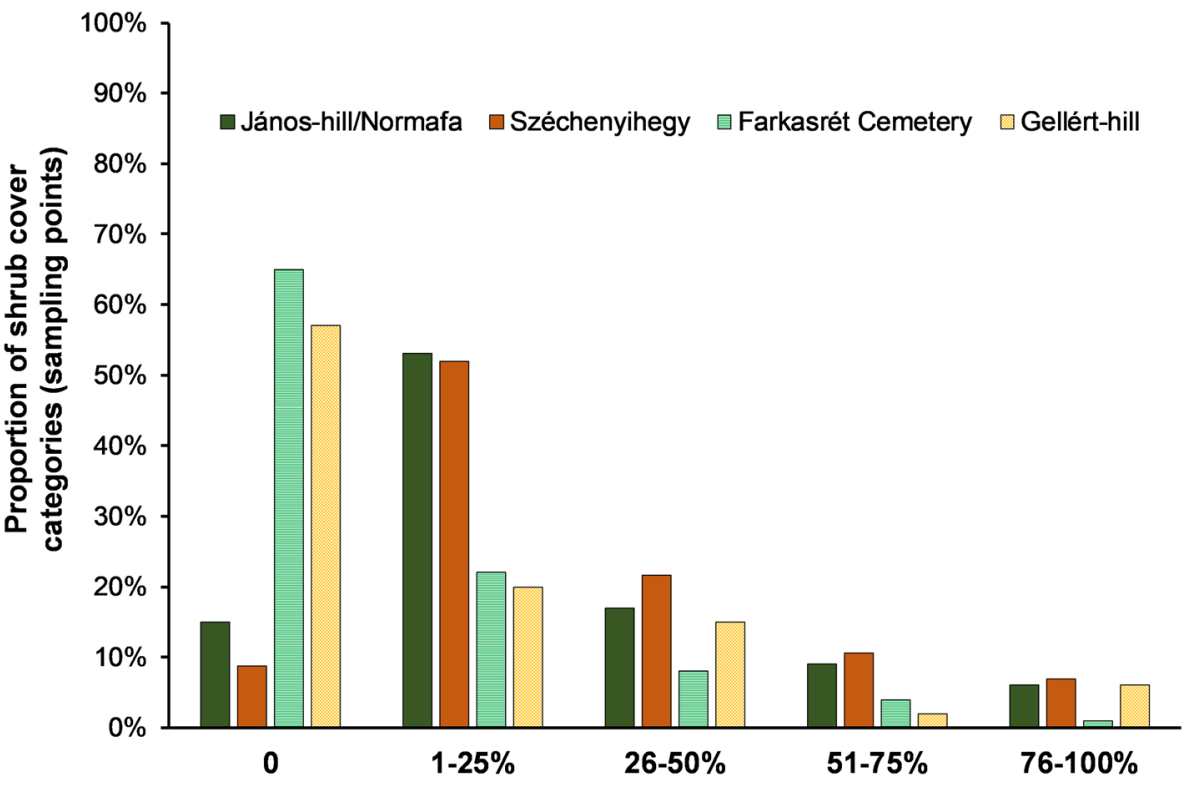

centre of Budapest. The shrub layer was completely dominated by native species like hawthorn and Cornus spp. at János-hill. At Széchenyihegy these species were also found besides the dominant field maple and European bladdernut and composed almost $83 \%$ of the individuals, but the alien common lilac became also frequent. In the two inner sites the proportion of exotic shrub species individuals was around $50 \%$ at Farkasrét Cemetery and 35\% at Gellért-hill.

At János-hill shrub species providing potential food for the wild boars included hawthorn, Cornus spp., black elder, dog rose (Rosa canina), blackthorn (Prunus spinosa), bramble (Rubus spp.) and bladdernut. Hawthorn, Cornus spp. and the bladdernut were available at Széchenyihegy too, but additional food sources like Prunus and Malus species were also present. At Farkasrét Cemetery only Rosa species and black elder formed the shrub food supply, but at Gellérthill Prunus species, European cornel, common hackberry (Celtis occidentalis) and common fig (Ficus carica) also occurred besides them as accessible food sources. The proportion of the plant individuals in the woody understory considered as favourable food for wild boars was $68 \%$ at János-hill, and was between 25 and $28 \%$ at the other three sites. These proportions of the favourable shrubs differed significantly among the four study sites (Chi square test: df $\left.=3, \chi^{2}=54.19, P<0.0001\right)$ (Fig. 3, Table 1).

At the canopy level the peripheral sites were dominated by oaks, while at the central ones ashes were more abundant. At János-hill and Normafa all the trees were native ones, while at Széchenyihegy almost $93 \%$ of the tree individuals represented a native species. The proportions of the nonindigenous tree species individuals at the two inner sites were not as high as at the shrub layer; $20.1 \%$ and $21.2 \%$ at Farkasrét Cemetery and Gellért-hill, respectively.

At János-hill the fruits and seeds of oaks, beech, checker tree (Sorbus torminalis) and wild cherry fall to the ground from the canopy level giving preferable food sources to wild boars. At Széchenyihegy seeds of European black pine (Pinus nigra) formed an additional food resource to these ones. At the Farkasrét Cemetery the tree species providing edible food for wild boars included only walnut ( Juglans spp.) and Prunus species, while at Gellért-hill, besides them, oaks, Turkish hazel (Corylus colurna), golden rain tree (Koelreuteria paniculata), common hackberry and treesized hawthorn were also present in low proportion. 
Fig. 3 Proportion of individuals of woody species in the understory and overstory providing potential food sources to wild boars in the four study sites

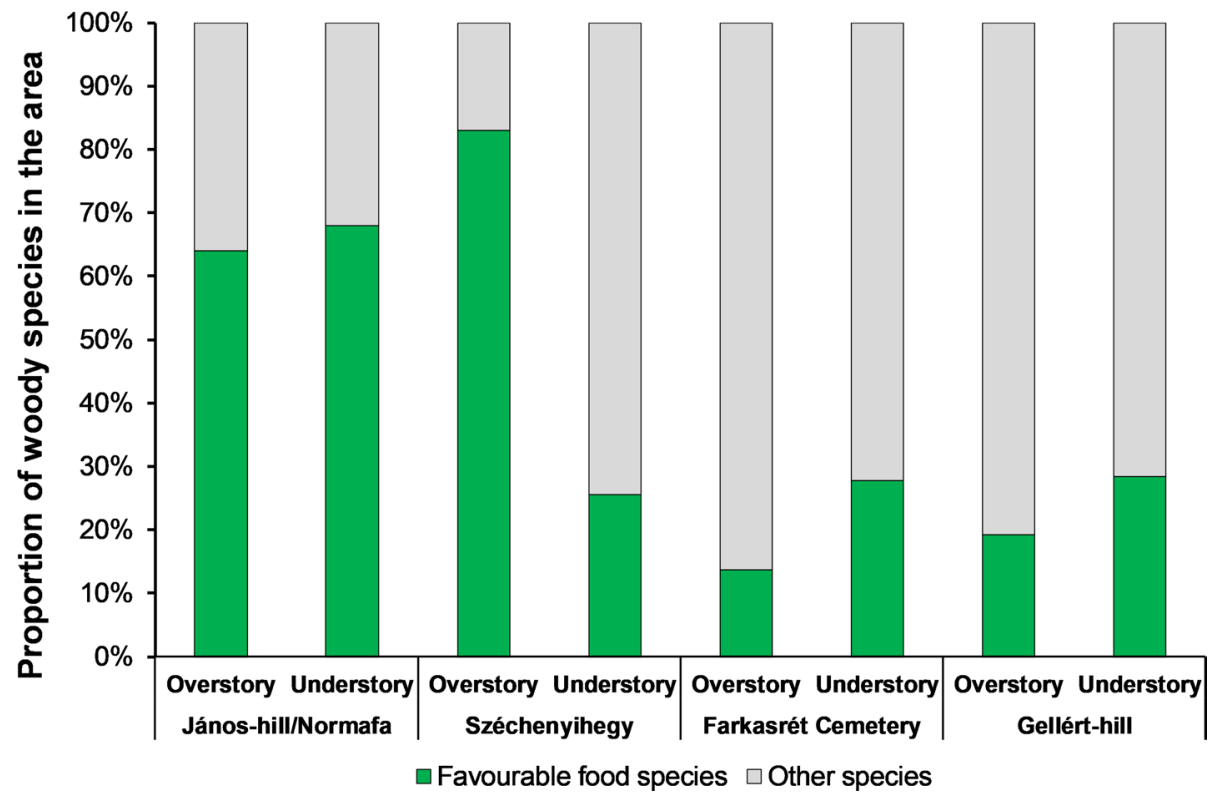

The proportion of the tree individuals that can provide favourable food for wild boars was $64 \%$ at János-hill and $83 \%$ at Széchenyihegy, but only 14\% at Farkasrét Cemetery and 19\% at Gellért-hill. Therefore, the proportion of favourable tree species was significantly different among the four study sites (Chi square test: $\mathrm{df}=3, \chi^{2}=139.1, P<0.001$ ) (Fig. 3, Table 2).

Signs of wild boar occurrence notably decreased from the edge of the city towards the centre (Fig. 4). At János-hill wild boar rooting was revealed at $42 \%$ of the sampling points (in $31 \%$ less than $25 \%$ of the sample circle was rooted, while in case of the rest $11 \%$ it ranged between 26 and $100 \%$ ). At Széchenyihegy rooting was found at only $7.5 \%$ of the sampling points. Based on these $14.5 \%$ and $3.13 \%$ of the total ground surface was rooted at János-hill and Széchenyihegy, respectively. Contrarily, at Farkasrét Cemetery and Gellért-hill no rooting was found at all. At János-hill $48 \%$ of the rooting disturbed only the litter, $33 \%$ affected the upper soil and $19 \%$ was registered as a deeper soil disturbance.

\section{Discussion}

Although the number of conflicts related to urbanizing wildlife is continuously rising, managing this process is not an easy task and demand complex solutions. For a long time,
Fig. 4 Occurrence of wild boar in the four study sites

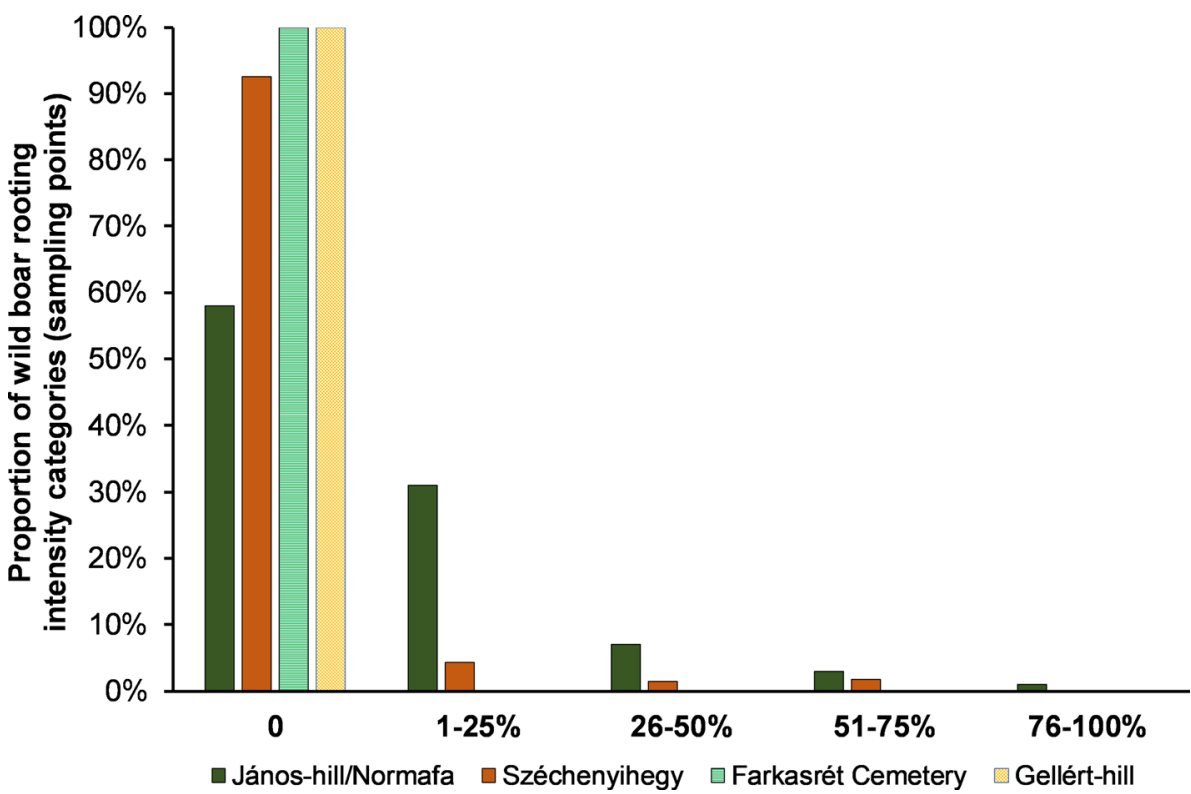


experts and managers have considered the cities as barren wastelands not as complex ecological environment. Thus, the necessary attention was not paid to these urban habitats. Investigations on the urbanization of the wildlife were delayed and many important aspects are still less researched (Adams 2005; Seymour et al. 2006). At the same time urban occurrences of wild boar have become more and more common in Europe or in Asia (Ikeda et al. 2019). In Hungary, wild boar is a hunted species, consequently the solution of the species-related problems is also expected from the part of game managers.

However, from their perspective restraining the urban human-wildlife conflicts and damages is rather difficult. Areas within the city boundaries usually fall outside of the legal hunting grounds, using firearms is prohibited in populated urban areas and capturing game animal in urban areas also requires authorization every single time. Moreover, wildlife managers are not allowed to modify urban habitats, they do not have control over the urban environment, the available habitats and food for the wild boars (Bogdán and Heltai 2014).

Nevertheless, if direct population control (i.e. hunting) is not a real option in cities, one of the most effective solutions could be the modification of urban habitats. It would include the degradation of habitat suitability and resource availability to reduce the attractiveness of the area for wild boars. During the planning of the vegetation structure of a city the designers take many aspects into account, but impeding the urbanization of wild boar and the inherent conflicts has not been considered yet.

Our study revealed that wild boar is present in Budapest, but its penetration into the central areas of the capital is not a fast process, although it is expected. Our results showed that the more centrally located green areas are less appropriate habitats for wild boars, providing less hiding place, and less favourable food sources from woody species. These inner patches do not have any direct connections with the woodlands around the city like the corridors and stepping stones in Barcelona, which can enhance this penetration process (Castillo-Contreras et al. 2018), they seem to be hardly reachable fragments. Our data confirmed that wild boar abundance is sharply decreasing along an urban gradient towards the centre; we did not register any wild boar rooting at Farkasrét Cemetery and Gellért-hill. Although the staff of the Cemetery reported that they experienced occasional wild boar damages around the gravestones in the previous years, but the reconstruction of the fence solved these problems.

At the area of János-hill and Normafa and Széchenyihegy the occurrence of wild boars is permanent. Our motion-sensing cameras set up at different baiting sites at the boundaries of Budapest registered the frequent appearance of single individuals or larger groups. Although, these areas are inside the borders of the city they also serve as natural habitats for wild boar. The woody plant species composition of these two study sites were quite natural dominated by native species. However, at Széchenyihegy alien species also appeared with a relatively higher ratio compared to János-hill, probably due to the vicinity of the more densely populated urban areas and the inherent propagule infestation pressure of non-natives species. At both sites the proportion of the oaks were relatively high which can provide the most preferred basic food source for wild boars, the oak acorns (Katona and Heltai 2018). Additionally, both sites had a quite rich understory which can provide adequate shelter the animals.

Contrarily, the understory at Farkasrét Cemetery and Gellért-hill was rich in non-native species, but poor in regards of favourable ones to wild boar, and though at the overstory the proportion of non-native species was not as high as in the shrub layer but the proportion of favourable species showed similarly low values. This pattern was probably due to the fact that at these two sites the overstory was dominated mainly by ashes and maples. Therefore, at the area of the Farkasrét Cemetery and Gellérthill stable occurrence of wild boars is not expected since these areas are more disturbed, isolated and less natural combined with the lower proportion of favourable food resources. Thus, it requires from the entering individuals a better adaptability, learning of new behaviour traits and deployment of unusual sources.

We can conclude that the adequate and natural vegetation in the urban environment not only serves as a shelter but also means the preferred food sources to which wild boars are adapted by their foraging behaviour and digestive characteristics. Consequently, it should not be a coincidence that dietary studies of urbanized wild boars in Budapest showed the primary consumption of natural food supply, and less importance of human-originated food sources (Heltai et al. 2016c; Katona et al. 2018), similarly to Berlin (Stillfired et al. 2017b), but not like in Islamabad, where garbage was the main food component of the wild boar (Hafeez et al. 2011).

The presence of appropriate shelter and feeding site can lead to stable urban wild boar populations like in many other European cities (Cahill et al. 2012; Licoppe et al. 2013; Massei et al. 2015; Stillfried et al. 2017a), which then can lose connections with the source population. Therefore, contrary to the popular opinion game managers should somehow manage the urban populations locally within the city boundaries and as-at least partly independent—biological and legislative units also in Hungary, like in the Anglo-Saxon countries (Adams 2016), but the complicated legal situation still prohibits this managing approach (Heltai et al. 2016a, b). 


\section{Conclusion for future biology}

The attitude of the residents towards wildlife basically changed in the recent years. People living in the cities distanced from the direct interaction with wildlife in urbanized societies and the urban perspective on wildlife become more individualized and emotional (Patterson et al. 2003). These changes shape the decisions of the local bodies. According to a survey in the USA the majority of the urban human population associates positive features to the wildlife (Seymour et al. 2006). Therefore, e.g. in Berlin, the residents expect that the wildlife conflicts will be handled in the most humane way as possible, preferably avoiding lethal solutions (Kotulski and König 2008).

Considering this alteration in attitudes we recommend to monitor urban wild boar presence and evaluate the quality of urban green patches from the point of view of wild boar to prevent or mitigate problems related to the species. Our methods used in this study or complex methodologies to describe the relationships between habitat quality of forested areas and ungulate impact on habitats and vegetation (Fehér et al. 2014; Katona et al. 2015) could be simply used for this purpose.

Increase and expansion of underharvested wild boar populations surely lead to their frequent appearance in growing human-built environments. Maintaining the biodiversity values of the cities, but decreasing the accessibility and quality of the urban habitats and their resources for the generalist, opportunistic, omnivorous wild boar is clearly a big challenge and requires the thoughtful cooperation of all managers of urban game populations and their habitats. Basic solutions can include translocation of the problem-individuals by live-capturing and targeted shooting or bow-hunting, or fencing of sensitive areas and the modification of the density and the species composition of shrub and canopy layer in non-fenced areas.

Acknowledgements Open access funding provided by Szent István University (SZIE). We are grateful to our students helping us in the field data collections. Pilis Parkforest Joint-Stock Company cooperated with us in the planning and conduction of this work.

Authors' contributions D. S conducting field work, data analysis and writing paper; M. H. leader of the project funded by the Ministry, in which the actual research was also performed, research planning, giving helpful comments to the manuscript. K. K. leader of the actual research, research planning, organisation and conducting field work, data analysis, writing paper.

Funding The research was funded by the Ministry of Agriculture (EVGF/827/2017). D. Sütô, as a PhD student, was supported by the Eötvös Loránd University. The publication is supported by the
EFOP-3.6.3-VEKOP-16-2017-00008 project (M. Heltai). The project is co-financed by the European Union and the European Social Fund.

\section{Complaince with ethical standards}

Conflict of interest Authors make a statement that they have no conflict of interest.

Ethical statement No ethical issues were raised during the investigation. The investigations did not cause any damage or significant disturbance to any living organism, animal or plant individual studied.

Data accessibility Data can be available directly from the Authors upon request on an individual basis.

Open Access This article is licensed under a Creative Commons Attribution 4.0 International License, which permits use, sharing, adaptation, distribution and reproduction in any medium or format, as long as you give appropriate credit to the original author(s) and the source, provide a link to the Creative Commons licence, and indicate if changes were made. The images or other third party material in this article are included in the article's Creative Commons licence, unless indicated otherwise in a credit line to the material. If material is not included in the article's Creative Commons licence and your intended use is not permitted by statutory regulation or exceeds the permitted use, you will need to obtain permission directly from the copyright holder. To view a copy of this licence, visit http://creativecommons.org/licenses/by/4.0/.

\section{References}

Adams LW (2005) Urban wildlife ecology and conservation: a brief history of the discipline. Urban Ecosys 8(2):139-156. https://doi. org/10.1007/s11252-005-4377-7

Adams CE (2016) Urban wildlife management. CRC Press, Boca Raton

Antrop M (2004) Landscape change and the urbanization process in Europe. Land Urban Plann 67(1-4):9-26. https://doi.org/10.1016/ S0169-2046(03)00026-4

Aronson MFJ, Lepczyk CA, Evans KL, Goddard MA, Lerman SB, MacIvor JS, Nilon CH, Vargo T (2017) Biodiversity in the city: key challenges for urban green space management. Front Ecol Environ 15:189-196. https://doi.org/10.1002/fee.1480

Bateman PW, Fleming PA (2012) Big city life: carnivores in urban environments. J Zool 287:1-23. https://doi.org/10.111 1/j.1469-7998.2011.00887.x

Bogdán O, Heltai M (2014) A vaddisznó előfordulásának vizsgálata Budapesten. Vadbiológia 16:87-96

Bordás I, Tompa A (2006) Mérgező növények, növényi mérgek. Országos Kémiai Biztonsági Intézet, Budapest

Cahill S, Llimona F, Cabañeros L, Calomardo F (2012) Characteristics of wild boar (Sus scrofa) habituation to urban areas in the collserola natural park (Barcelona) and comparison with other locations. Anim Biodiv Conserv 35:221-233

Castillo-Contreras R, Carvalho J, Serrano E, Mentaberre G, FernándezAguilar X, Colom A, González-Crespo C, Lavín S, López-Olvera JR (2018) Urban wild boars prefer fragmented areas with food resources near natural corridors. Sci Total Environ 615:282-288. https://doi.org/10.1016/j.scitotenv.2017.09.277

Ciach M, Fröhlich A (2019) Ungulates in the city: light pollution and open habitats predict the probability of roe deer occurring 
in an urban environment. Urban Ecosys 22:513-523. https://doi. org/10.1007/s11252-019-00840-2

Cohen B (2006) Urbanization in developing countries: current trends, future projections, and key challenges for sustainability. Technol Soc 28:63-80. https://doi.org/10.1016/J.TECHSOC.2005.10.005

Costard S, Mur L, Lubroth J, Sanchez-Vizcaino JM, Pfeiffer DU (2013) Epidemiology of African swine fever virus. Virus Res 173:191197. https://doi.org/10.1016/j.virusres.2012.10.030

Csókás A, Heltai M (2016) Velünk lakik, vagy csak meglátogat? Erdőgazd Faipar 2:6-7

Ersoy E, Jorgensen A, Warren PH (2019) Identifying multispecies connectivity corridors and the spatial pattern of the landscape. Urban Forest Urban Green 40:308-322. https://doi.org/10.1016/j. ufug.2018.08.001

Fehér Á, Katona K, Bleier N, Hejel P, Szemethy L (2014) Monitoring of ungulate impact in Hungarian forested Natura 2000 sites. Rev Agricult Rural Dev 3:126-130

Fekete S, Gellér Z, Gerzanics AG, László JBE, Lászay G, Schmidt G, Szántó M, Szendrői J, Tillyné MA (2003) Növények a kertépítészetben. Mezőgazda Kiadó, Budapest

Hafeez S, Abbas M, Khan ZH, Rehman EU (2011) Preliminary analysis of the diet of wild boar (Sus scrofa 1., 1758) in Islamabad, Pakistan. Turkish J Zool 35:115-118. https://doi.org/10.3906/ zoo-0806-24

Heltai M, Antal C, Kovács F, Rácz K, Csépányi P, Nagy A, Csókás A, Schally G, Csányi S (2016a) A vaddisznó budapesti előfordulásának jogi és biológiai háttere I. Erdészeti Lapok 150:154-156

Heltai M, Antal C, Kovács F, Rácz K, Csépányi P, Nagy A, Csókás A, Schally G, Csányi S (2016b) A vaddisznó budapesti előfordulásának jogi és biológiai háttere II. Erdészeti Lapok 150:191-194

Heltai M, Kovács F, Rácz K, Csepányi P, Nagy A (2016c) A vaddisznó táplálkozásának vizsgálata lakott környezetben, Budapesten. Vadbiológia 18:27-34

Herr J, Schley L, Roper TJ (2009) Socio-spatial organization of urban stone martens. J Zool 277(1):54-62. https://doi.org/10.111 1/j.1469-7998.2008.00510.x

Ikeda T, Kuninaga N, Suzuki T, Ikushima S, Suzuki M (2019) Touristwild boar (Sus scrofa) interactions in urban wildlife management. Glob Ecol Conser 18:e00617. https://doi.org/10.1016/J.GECCO .2019.E00617

Jokimäki J, Kaisanlahti-Jokimäki M-L, Suhonen J, Clergeau P, Pautasso M, Fernández-Juricic E (2011) Merging wildlife community ecology with animal behavioral ecology for a better urban landscape planning. Land Urban Plann 100:383-385. https://doi. org/10.1016/j.landurbplan.2011.02.001

Katona K, Heltai M (2018) A vaddisznó táplálék-összetételének és táplálkozási sajátságainak szakirodalmi áttekintése. Tájökol Lapok 16:65-74

Katona K, Fehér Á, Bleier N, Hejel P, Szemethy L (2015) Patások erdei élőhelyeken tapasztalható hatásainak felmérése: a vadhatás monitoring. Vadbiológia 17:1-7

Katona K, Lakatos EA, Márton M, Szabó L, Csókás A, Csányi S, Heltai M (2018) Feeding habits of urban wild boar in Budapest, Hungary. In: 6th international wildlife and game management symposium. Sofia, Bulgaria

Kotulski Y, König A (2008) Conflicts, crises and challenges: wild boar in the Berlin City - a social empirical and statistical survey. Nat Croatica 17:233-246

Licoppe A, Prévot C, Heymans M, Bovy C, Casaer J, Cahill S (2013) Wild boar/feral pig in (peri-)urban areas. In: International survey report as an introduction to the workshop: managing wild boar in human-dominated landscapes International Union of Game Biologists, pp 1-31. Brussels: Congress IUGB 2013

Luniak M (2004) Synurbization: adaptation of animal wildlife to urban development. In: WW Shaw, LK Harris, L VanDruff (eds)
Proceedings of the 4th international symposium on urban wildlife conservation. Tuscon, Arizona, USA

Lyytimäki J, Petersen LK, Normander B, Bezák P (2008) Nature as a nuisance? Ecosystem services and disservices to urban lifestyle. Environ Sci 5:161-172. https://doi.org/10.1080/1569343080 2055524

Mackenstedt U, Jenkins D, Romig T (2015) The role of wildlife in the transmission of parasitic zoonoses in peri-urban and urban areas. Int J Parasit Parasit Wildlife 4:71-79. https://doi.org/10.1016/j. ijppaw.2015.01.006

Massei G, Kindberg J, Licoppe A, Gačić D, Šprem N, Kamler J, Baubet E, Hohmann U, Monaco A, Ozoliņš J, Cellina S, Podgórski T, Fonseca C, Markov N, Pokorny B, Rosell C, Náhlik A (2015) Wild boar populations up, numbers of hunters down? A review of trends and implications for Europe. Pest Manag Sci. https://doi. org/10.1002/ps.3965

Meng XJ, Lindsay DS, Sriranganathan N (2009) Wild boars as sources for infectious diseases in livestock and humans. Phil Trans Royal Soc B Biol Sci 364:2697. https://doi.org/10.1098/ RSTB.2009.0086

Molnár Z, Tatai Z, Zétényi D, Orosz I, Horváth A, Becsák P, Pálvölgyi T, Simon A (2017) Budapest Környezeti Programja 2017-2021. Budapest

Patterson ME, Montag JM, Williams DR (2003) The urbanization of wildlife management: social science, conflict, and decision making. Urban Forest Urban Green 1:171-183. https://doi. org/10.1078/1618-8667-00017

Podgórski T, Baś G, Jędrzejewska B, Sönnichsen L, Śnieżko S, Jędrzejewski W, Okarma H (2013) Spatiotemporal behavioral plasticity of wild boar (Sus scrofa) under contrasting conditions of human pressure: primeval forest and metropolitan area. J Mammal 94(1):109-119. https://doi.org/10.1644/12-MAMM-A-038.1

Sánchez-Vizcaíno JM, Mur L, Gomez-Villamandos JC, Carrasco L (2015) An update on the epidemiology and pathology of African swine fever. J Comput Pathol 152:9-21. https://doi.org/10.1016/j. jcpa.2014.09.003

Schilthuizen M (2018) Darwin comes to town: how the urban jungle drives evolution. Picador, New York

Seymour M, Byrne J, Martino D, Wolch J (2006) Recreationist-Wildlife Interactions in Urban Parks. The Green Visions Plan for 21st Century Southern California

Stillfried M, Fickel J, Börner K, Wittstatt U, Heddergott M, Ortmann S, Kramer-Schadt S, Frantz AC (2017a) Do cities represent sources, sinks or isolated islands for urban wild boar population structure? J Appl Ecol 54:272-281. https://doi.org/10.1111/1365-2664.12756

Stillfried M, Gras P, Busch M, Börner K, Kramer-Schadt S, Ortmann S (2017b) Wild inside: urban wild boar select natural, not anthropogenic food resources. PLoS ONE 12:e0175127. https://doi. org/10.1371/journal.pone.0175127

Tari T, Sándor G, Náhlik A (2018) The presence of wild boar in urban areas of Hungary. In: 12th international symposium on wild boar and other Suids, vol 79

Toger M, Benenson I, Wang Y, Czamanski D, Malkinson D (2018) Pigs in space: an agent-based model of wild boar (Sus scrofa) movement into cities. Land Urban Plann 173:70-80. https://doi. org/10.1016/j.landurbplan.2018.01.006

Tóth-Ronkay M, Bajor Z, Bárány A, Földvári G, Görföl T, Halpern B, Leél-Ôssy S, Mészáros R, Péntek AL, Tóth B, Tóth Z, Vörös J (2015) Budapest. In: Kelcey JG (ed) Vertebrates and Invertebrates of European Cities: selected non-Avian Fauna Berlin. Springer, New York, pp 27-73. https://doi.org/10.1007/978-1-4939-1698-6

United Nations, Department of Economic and Social Affairs, P. D. (2019) World Urbanization Prospects 2018: Highlights (ST/ESA/ SER.A/421). Retrieved from https://population.un.org/wup/ 